\title{
NSC-87877 Inhibits Dual-specificity Phosphatase 23 (DUSP23) that Regulates ERK
}

\author{
Mina Song and Sayeon Cho \\ College of Phamacy, Chung-Ang Lnwersity, Seoul 156-756, Korea. E-mail: sychoatcanackr \\ Received June 8, 2009. Accepted June 26, 2009
}

Key Wonds: DUSP23, NSC-87877, PTP inhibitor

Phosphorylation and dephosphorylation of proteins comprise important regulatory pathways that are involved in the control of cell growth. differentiation adhesion and death. ${ }^{1.23}$ This process requires the combined action of protein kinases and phosphatases. Protein phosphatases are generally divided into two classes: protein serine/threonine phosphatase and tyrosine specific phosphatase. The sequencing of the human genome has revealed 107 protein ty rosine phosphatases (PTPs). ${ }^{4}$ The dual-specificity phosphatases (DUSPs) are subclass of the PTP superfamily and can dephosphorylate both phosphoty rosine and phosphoserine/phosphothreonine residues within the same protein. DUSPs can be grouped into six subgroups on the basis of sequence simularity that include slingshots. phosphatases of regenerating liver (PRLs). Cdc 14 phosphatases. phosphatase and tensin homologues deleted on chromosome 10 (PTENs). myotubularins. mitogen-activated protein kinase phosplatases (MKPs) and aty pical DUSPs. ${ }^{5}$ MKPs exhibit distinct substrate specificities for various mitogen-activated protein kinases (MAPKs). different tissue distribution, subcellular localization. and different modes of inducibility of their expressions by extracellular stimuli. ${ }^{6.8 .9}$ The three major groups of MAPK that are expressed in mammals are p38. extracellular signal regulated kinase (ERK), c-Jun N-terminal kinase (JNK). MAPKs are ker signaling enzymes that regulate proliferation, cell survival and death, differentiation. development, immune function. gene expression. and other signaling cascades

Growing data presented that modulation of PTP enzy matic activities could have a role in regulating disease susceptibility. ${ }^{10}$ Therefore chemical compounds that regulate the activities of PTP may constitute a therapeutic approach for the treatment of diseases such as cancer. diabetes and inflammation.

NSC -87877 was originally identified as a potent inhibitor of Src homology region 2 ( $\mathrm{SH} 2$ ) domain-containing plosphatase 1 (SHP-1) and SHP-2 PTPs. Fig. 1 shows the structure of NSC-87877. We used NSC-87877 to identify more plosplatases that are targets of NSC-87877. The phosphatase inlibition screening led to the discovery of several phosphatases that<smiles>O=[N+]([O-])c1cc(/N=N/c2ccc3cc(S(=O)(=O)O)ccc3c2)c(O)c2ncccc12</smiles>

Figure 1. Chemical structure of NSC-87877. were effectively inhibited by NSC-87877.11.12,13.14 In this report. we show that DSUP23 is another target of NSC-87877. NSC -87877 inlubited DUSP23 with the inhibitory concentration 50 (IC 5 ) about $11.25 \pm 0.12 \mu \mathrm{M}$. When DUSP23 was treated with various concentrations of NSC-87877. DUSP23 inhibitory activity of NSC-87877 was dose-dependent (Fig. $2 A$ ). Analysis of the mode of inlibition indicated a competitive inhibition with $K_{\mathrm{j}}$ of $11.21 \mu \mathrm{M}$ (Fig. 2B). suggesting that NSC-87877 binds to the catalytic cleft of DUSP23.

Next we asked whether the inhibitory action of NSC. 87877 on DUSP23 influences the phosphorylation level of DUSP23 substrates. The MAPK substrates for DUSP23 remains to be clarified as two independent reports presented conflicting data. ${ }^{15.16}$ To make clear substrate specificity of DUSP23, we

A
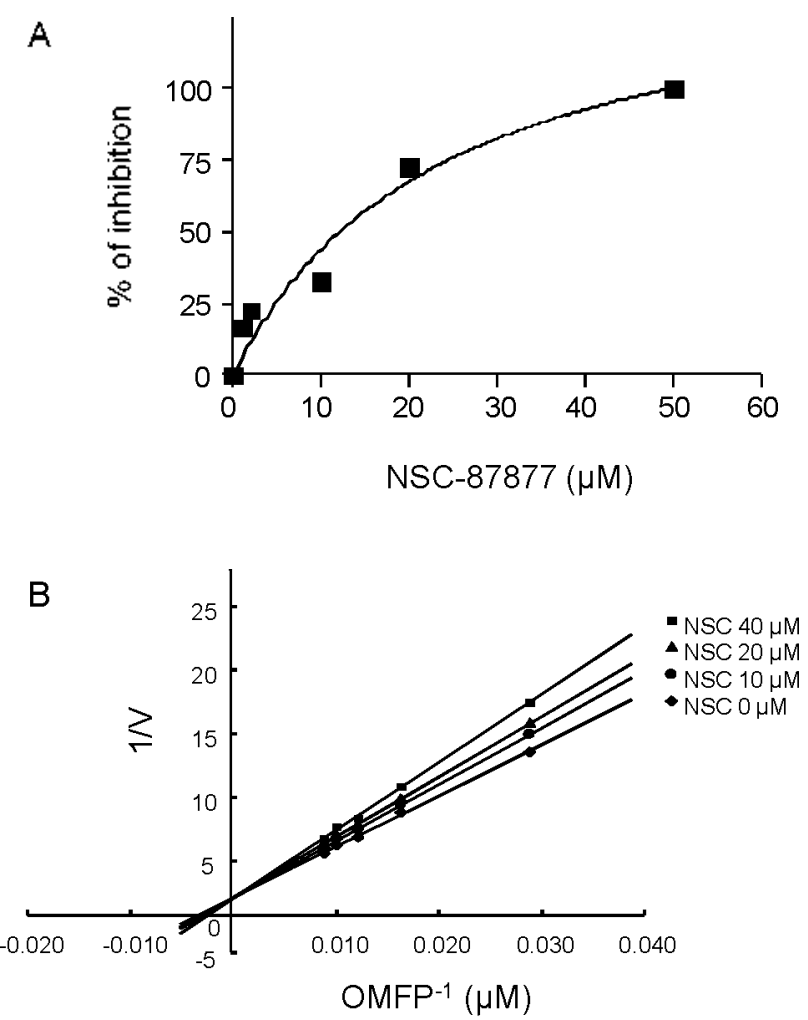

Figure 2. Inlibitory effect of NSC-87877 in DUSP23 and kinetic analysis of DUSP23 inhibition by NSC-87877 (A) DUSP23 was incubated with various concentrations of NSC -87877 at $37^{\circ} \mathrm{C}$ for 30 min. Fluorescence emission from the product was measured with a multiwell plate reader as described in Experimental section. (B) Lineweaver-Burk plot of DUSP23 was generated from the reciprocal data. 
A

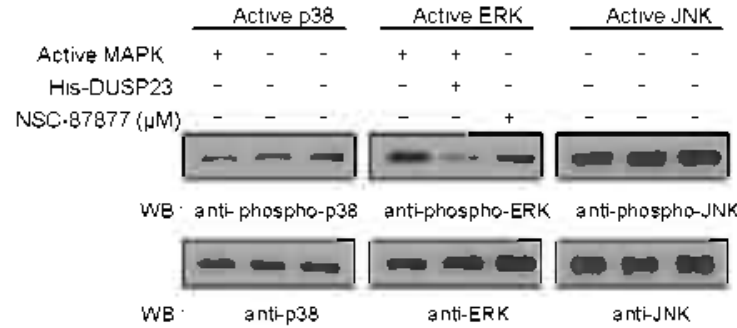

B

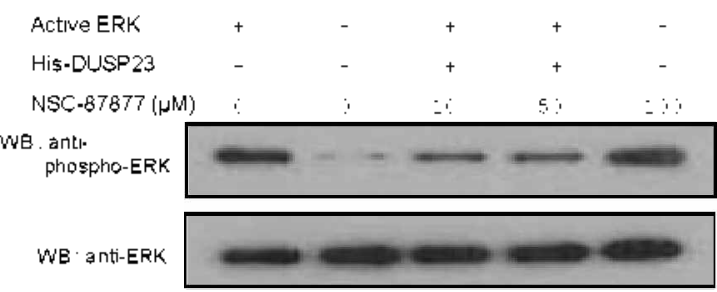

C

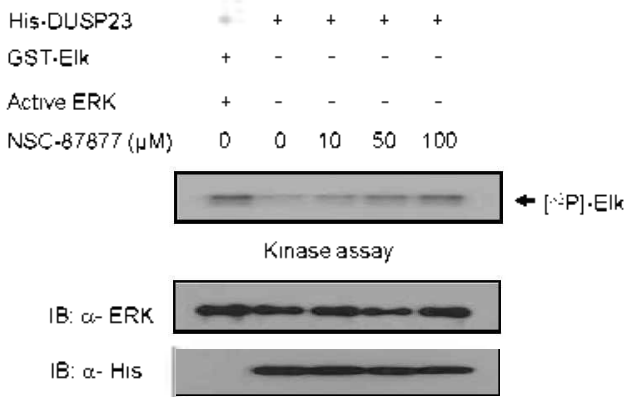

Figure 3. DUSP23 specifically dephosphorylates and inhibits ERK, and NSC-87877 inllibits the action of DUSP2 3 on ERK (A) Active recombinant MAPKs ( $\mathrm{p} 38$, ERK, or INK) were incubated in vitro with or without recombinant DUSP23 that was purified trom bacteria at $37^{\circ} \mathrm{C}$ for $30 \mathrm{~min}$. Dephosphorylation levels of MAPKs were determined by Western blotting analysis using anti-phospho-MAPK antibodies. (B) DUSP23 and phospho-ERK were incubated with NSC-87877 $(0,50$, or $100 \mu \mathrm{M})$ and the Western blotting analysis was perforned as described in Experimental section. (C) DUSP23 (1 $\mu \mathrm{g}$ ) was pre-mixed with various NSC-87877 concentrations as indicated and then incubated with active ERK. ERK activities were deternined by kinase assay s using GST-Elk as a substrate. Samples were resolved by SDS-PAGE and subjected to autoradiography.

performed in vitro dephosphorylation assays with the active recombinant MAPKs that were phosphorylated in the activation loops. As shown in Fig. 3A. DUSP23 effectively dephosphorylated the active phosphorylated ERK and the dephosphorylation of ERK by DUSP23 was blocked in the presence of NSC - 87877. In contrast, dephosphorylation of $\mathrm{p} 38$ and JNK by DSUP23 was not observed (Fig. 3A). These data suggest that both $\mathrm{p} 38$ and JNK are not direct targets of DUSP23.

The dose dependence of NSC-87877 on DUSP23-mediated ERK dephosphory lation was also examined. After treatment of phospho-ERK with DUSP23 in the presence of various concentrations of NSC-87877, the change in ERK phosphorylation level was determined with Western blotting analysis. As shown in Fig. 3B. DUSP23-mediated dephosphorylation of ERK was inhibited by NSC-87877 in a dose-dependent manner. Taken together. these data suggest that DUSP23 targets ERK and NSC-87877 treatment reduces DUSP23 phosphatase activity.

We additionally examined the effects of DUSP23 on ERK activity using an in vitro kinase assays. Kinase activity of ERK towards GST-Elk as a substrate was decreased in the present of DUSP23. And NSC-87877 blocked this inhibitory effect (Fig. 3C). These results inply that DUSP23 specifically dephosphorylates and inlibits ERK and NSC-87877 inlibits the action of DUSP23 on ERK.

In the present study. the results of our study suggest that NSC-87877 is a potent competitive inhibitor of DUSP23. DUSP23 dephosphorylates and inactivates ERK but has no activity on JNK and $\mathrm{p} 38$. Since NSC-87877 inhibited dephosphorylation of ERK by DUSP23, our results will provide the basis for developing a DUSP23-specific inhibitor that activates ERK signaling pathway:

\section{Experimental Section}

Antibodies. Anti-ERK, anti-phospho-JNK (specific for phospho-Thr183 and phospho-Tyrl85). anti-phospho-p38 (phospho-Thr180 and phospho-Tyr182), and anti-phosphoERK (phospho-Thr202 and phospho-Ty 204) antibodies were purchased from Cell Signaling Technology (Danvers. MA). Anti-JNK and anti-p38 antibodies were from Santa Cnuz Biotechnology (Santa Cruz, CA). Active JNK and active p38 proteins were from Upstate Biotechnology (Lake Placid, NY). Active ERK protein was from Millipore (Bedford. MA).

Purification of $6 x$ His-tagged proteins. Purification of reconbinant proteins were caried out as previously described. ${ }^{13}$

In vitro phosphatase assays and linetic analysis. In vito Phosphatase assay's and Kinetic analy sis were carried out as previously described. ${ }^{1+}$

Westem blotting analysis. Westen blotting was carried out as previously described. "I?

Dephosphorylation assays with active phosphorylated MAPKs. $6 \times$ His-tagged DUSP23 $(1 \mu \mathrm{g})$ was combined with active phosphorylated p38 (10 ng). ERK (10 ng), or JNK (20 $\mathrm{ng}$ ) in PTP assay buffer ( $30 \mathrm{mM}$ Tris- $\mathrm{HCl}(\mathrm{pH} 7) .75 \mathrm{mM}$ $\mathrm{NaCl}, 1$ mMEDTA. 0.1 mMDTT. $0.33 \% \mathrm{BSA}$ ) in a total reaction volume of $30 \mu \mathrm{L}$. and incubated for 30 nin at $37^{\circ} \mathrm{C}$. To deternine whether NSC-87877 down-regulates DUSP23 effect on ERK in vitro, $1 \mu \mathrm{g}$ of DUSP23 was mixed with $10 \mathrm{ng}$ active phosphorylated ERK and various NSC-87877 concentrations $(0$. 50 , or $100 \mu \mathrm{M}$ ) in a $30 \mu \mathrm{L}$ reaction volume and incubated for $30 \mathrm{~min}$ at $37^{\circ} \mathrm{C}$. The samples were subjected to Westem blotting analysis to examine the phosphorylation state of MAPKs using the phospho-MAPK antibodies.

In vitro kinase assay. $6 \times$ His-tagged DUSP2 $3(1 \mu \mathrm{g})$ was pre-mixed with various NSC -87877 concentrations $(0,50$, or $100 \mu \mathrm{M}$ ) in PTP assay buffer for $30 \mathrm{~min}$ at $37^{\circ} \mathrm{C}$ and then further incubated in the presence of active phosphorylated ERK ( $10 \mathrm{ng}$ ) for $30 \mathrm{~min}$ at $37^{\circ} \mathrm{C}$. Kinase reactions were initiated by mixing the pre-incubated samples with kinase reaction buffer (20 mM Tris- $\mathrm{HCl}$ (pH 7.5), $20 \mathrm{mM} \mathrm{MgCl}=0.1 \mathrm{mM}$ sodium orthovanadate. $1 \mathrm{mMDTT}$ ) supplemented with $20 \mu \mathrm{M}$ ATP $/ 10 \mu \mathrm{Ci}\left[\gamma^{\left.3{ }^{3}-\mathrm{P}\right] \mathrm{ATP}}\right.$ and $1 \mu \mathrm{g}$ of Elk as a substrate. After $30 \mathrm{~min}$ at $30^{\circ} \mathrm{C}$. reactions were terminated by addition of SDS-PAGE sample buffer and the products of kinase reactions 
were separated by SDS-PAGE for autoradiography. The gels were dried and exposed to X-ray film.

Acknow ledgments. This work was supported by a grant of the Korea Health 21 R\&D Project. Ministry of Health \& Welfare. Republic of Korea (A01-0385-A70604-07M7-00040B).

\section{References}

1. Yarden, Y; Ullrich, A. Amm. Rev Biochem. 1988, 57, 443-478.

2. Hunter, T. Cim: Opin. Cell. Biol. 1989, 1(6), 1168-1181.

3. Ullrich, A.; Schlessinger, T. Cell 1990, 6I(2), 203-212.

4. Alonso, A.; Sasin, J.; Bottini, N.; Friedberg, I.; Friedberg, I.; Osternan1, A.: Godzik, A.; Hunter, T.; Dison, J.; Mustelin, T. Cell 2004, 117(6), 699-711.

5. Patterson, K. I.; Brumuner, T:: O'Brien, P. M.: Daly, R. T. Biochem. J. 2009. $118(3), 475-489$

6. Chen, L.: Sung, S. S.: Yip, M. L.: Lawrence, H. R.: Ren, Y.: Guida, W. C.; Sebti, S. M.; Lawrence, N. T.; Wu, J. Mol Phamacol.
2006. $76(2), 562-570$.

7. Dickinson, R. J.: Keyse, S. M. J. Cell Sci. 2006, 119(Pt 22), $4607-4615$.

8. Dixon, D.; Moyana, T.: King, M. I. Exp. Cell Res. 1998, 2ł/(2), $236-243$.

9. Srikanth, S.; Franklin, C. C.: Duke, R. C.; Kraft, R. S. Mol. Cell Biochem. 1999, 199(1-2), 169-178.

10. Fischer, E. H.; Charbonneau, H.; Tonks, N. K. Science 1991. $25360018) .401-406$

11. Song, M: Cho, S. Bull. Koren Chem. Soc. 2009, 30(5), 1190-1192.

12. Song, M.; Cho, S. Bull. Korean Chem. Soc 2009, 30(4), 924-926.

13. Song, M.: Cho, S. Bull. Korean Chem. Soc 2009, 30(1), 236-238.

14. Song, M.; Park, J. E.; Park, S. G.; Lee do, H.; Choi, H. K.; Park, B. C.: Ryu, S. E.; Kim, J. H.: Cho, S. Biochem Biophys Res. Commun 2009, 381(4), 491-495.

15. Wu, Q.; Li, Y.; Gu, S.; Li, N.; Zheng, D.; Li, D ; Zheng, Z.; Ji, C.; Xie, Y; Mao, Y. Int. J. Biochem. Cell Biol. 2004, 36(8), 1542-1553.

16. Takagaki, K.; Satoh, T; Tanuma, N.; Masuda, K.; Takekawa, M.; Shima, H.: Kikuchi, K. Biochem. J. 2004. 383(Pt. 3). 447-455.

17. Cho, S. Bull. Korem Chem. Soc. 2005, 26(11), 1823-1825. 